\title{
3Hサッカ一戦術解析支援システムの開発
}

\section{Soccer Game Scene Analyser Support System}

\author{
○久本 賢 ラシキア・V \\ 岡山理科大学工学部情報工学科

\section{Satoshi Hisamoto Vakhtang Lashkia \\ Okayama University of Science}

\begin{abstract}
In this paper, we propose a motion analysis system for quantitative and qualitative evaluation of player's movements in soccer games. Real images taken by a fixed camera are processed by a computer. Positions of all players are detected using image segmentation techniques and real soccer game scenes are transformed to the computer animated scenes. This transformation gives possibility to analyze soccer games, by displaying "dominant regions" (a region where a player can arrive faster than all other players), or by displaving three-dimensional images from any position in the field.
\end{abstract}

Key word : Scene analysis, perspective transformation, image segmentation, virtualized soccer game

\section{1.はじめに}

現任、スホーツツの発展によりま寸ま寸高度な戦術が求 め心狄るようになってきている。また、試合に勝つため には、相手の戦術老知ることが、大変重琶視されている。 大扯の場㑒、人間の手により戦術解析は行执てきたが、

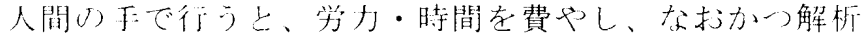

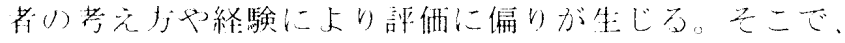
コンピュータ在導人し、定量的で時閒や学力存省くシス テムの作成在本研究では考えていく。

今圭でスボーツシーン在対象にした動画像解析の研究

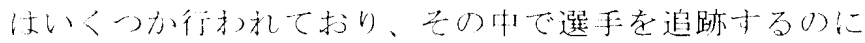
テンフレートマッチング処理老使用し、個々の選手索追 跡寺石研究が女る[1]、[2]。しかし、選于の交錯時に 别の選手を䛊って追跡寸るという問題があり、個人個人 在追跡寸るのは難しい。乙二で、本研究では画像間減算 によりすべての選于の座標在求め、選手の着ているユニ フォ一ムの色を元によ゙ちらのチームの選手かを判別する。 そのことにより個人に対する戦術解析は難しくなるが、 チーム全体の戦術を評価することが可能になる。戦術解 析には、ある領域にどちらのチームの選手が早く到達で きるかを表すことができる優勢領域を用いて行う。また 頭上小らの選手位置表示だけでなく $3 \mathrm{D}$ 表示毛行い、フ イールド内の視覚的情報をも解析できる上うにする。

\section{2. 処理少注}

本研究は、いくつかの段階で構成されている。まず最 初に、前処理としてフィールド上の直線在㭘出し、フィ 一ルドのラインの交点を求好。次に選手の中心座標を 求め、その座標を元に選手のコニフォ一ムの色を抽出す る。そして、その色により同ヂームの選手、異チームの
選手を認識し、アニメーションで表示を行う。ここで、 アニメーション表示する際、㛟出した選手の座標はカメ ラ画像の座標なのでフィールド内の実際の座標に変換す る。その時に、あらかじめ前処理で求めていた交点を使 用与及。鼠後に、戦術解析を行う。この戦術解析は、女

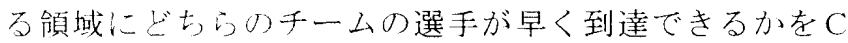
Gによって表寸。優勢領域は、パスを味方選手に向か力 て出さ寸゙に、味力選手が追いつける位置に出寸とき、ハ スコース在ふさぐときなどに大変有効な解析手段である。 さうに、つィールド内の選手の視点やまた、それとは別 にフィールド内のある地点からの視点がわかると、座標 だけな゙巽手位置在考えるよりも味方選手の前に相手選手 がいるこ上や、例え優勢領域であってもハスコースは全 てふさがれていること等存視覚的に知ることができ大変 便利である。

\section{1 前処理}

まずはじめにフィールド上に誰もいない状態で撮影した 部分を使いバックグラウンド画像を作る（図 1 . a )。

こり画像は画像間減算で用いるためファイルとして保存

しておく。

この画像から八フ変換により、まず綐のラインを検出 し、次に横のラインを検出する。そして、フィールドの 線分を検出し、ラインの交点の座標を読み取る（図 1 .

b、図 1 ，c）。この交点は、ビデオ映像から読み取っ た選手座標をC Gで表示するときの座標に変換するとき に使用寸る。

\section{2 選手検出処理}

人力画像（図 2, a ）からバックグラウンド画像（図 1.a）画像閒減算を行う（図2 . b )。そして、2 值化 し選手を検出する。网2，bのままでは影が現れたり、 


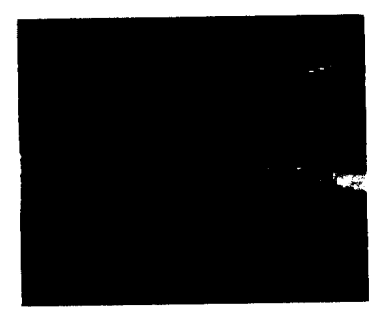

a. Background image

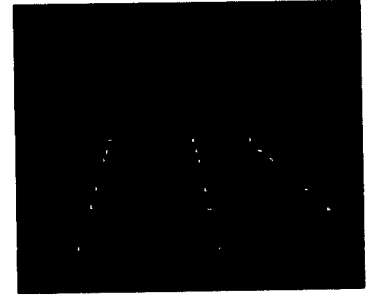

b. Detection of line

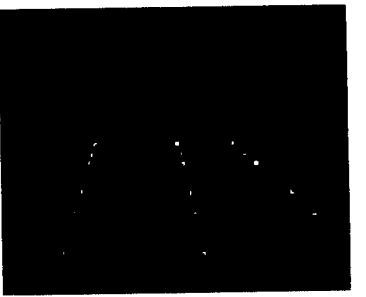

Detection of intersection

Fig 1. before first step

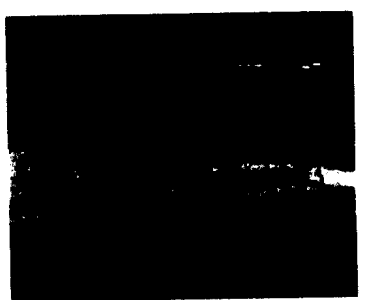

a. Source image

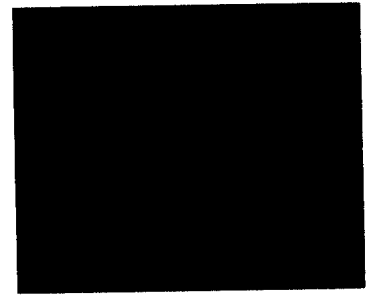

b. Image subtraction

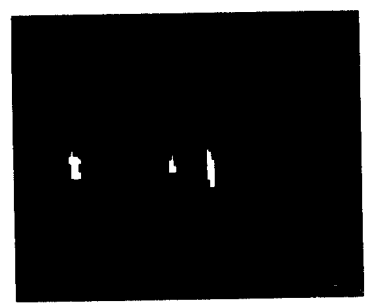

c. Dilation and

Fig 2. Detection of player

手足が胴体から離れてし末い・人の人間として検出でき なくなる場合がある。そこで、画素ごとに膨張・縮小処 理を行う（図2，c）。二の処理を行うこ上で雑音の除 去もできる。図2。cに扮いて、自い領域として残つた 部分は選手の画像情報がある部分で女る。そこで選手の 位置を求めるために、白い領域の座標を調べる。しかし、 白い領域は不規則な形老しているので、この门い領域在 先全に含むことのできる矩形を想定し、その座標（最人 值、最小值）を調バる。求めた矩形の座標から選手の中 心座標を求める。

中心座標を元に一定の大きさの矩形老設定し(䦷 3 )、 その矩形の寸心てての画素情報を取得し、色情城 $\mathrm{R}, \mathrm{G}, \mathrm{B}$ 值在求女る。 $\mathrm{R}, \mathrm{G}, \mathrm{B}$ 值は 0 2 255 ○值をとり、約 1600 う色女ることになるが、今回戊值在朋意し、全体で8 色に制限寸る。設定した矩形の中に8色の画素がそれぞ

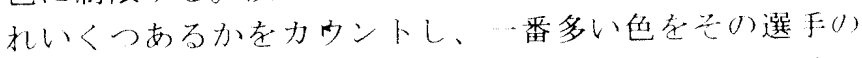
色上する。す心゙ての選手について以上の处理在行いムニ゙とに分ける。今国恃リアルタイムでの処理でなな

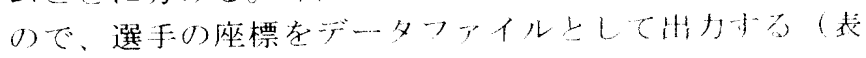

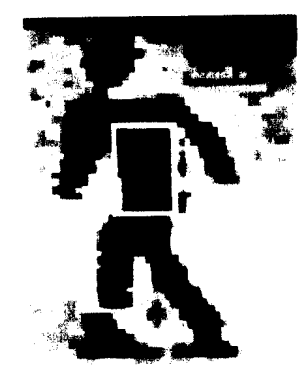

Fig 3 . Set rectangle for discriminating color

\begin{tabular}{|ccc|}
\hline Scene & $x$ & $y$ \\
0 & 174 & 004 \\
0 & 84 & 290 \\
1 & 174 & 203 \\
$\cdot$ & $\cdot$ & $\cdot$ \\
\hline
\end{tabular}

Team 1

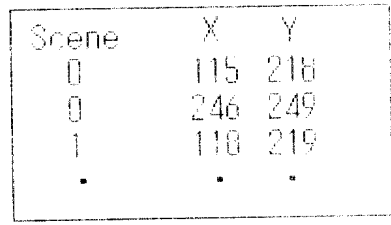

Team2
Tab 1. Write position data

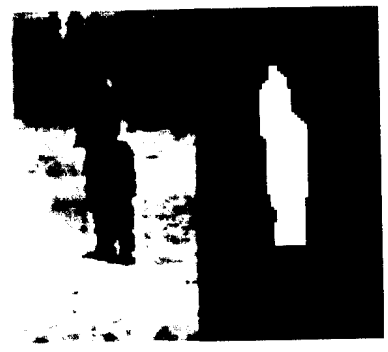

Fig 4. Cause of wrong detection

1，1チームに選手が 2 人の場合) チームム别に・ーイ

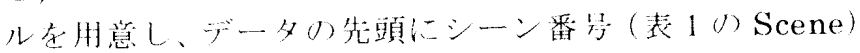

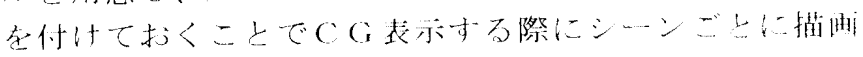
寸ることができる

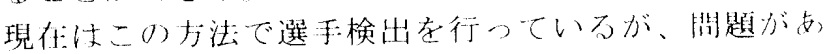

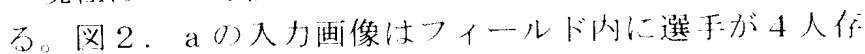
在している酔像で女るが、网2。では2人が雷なって いるので（図 4)、3人にしか見えない。この上りに選 手が重なっていると膨張・縮小処理在行った後の選正在 表才目小領域も重なり、一人の選手上して認識してし未

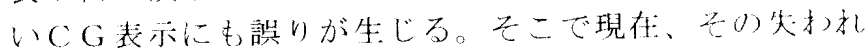

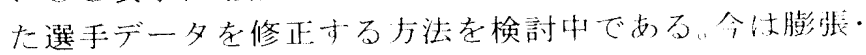
縮小処理画像から得ら扎大選手位置つ夾標（矩形の恼 標）在用いてその範囲だけの情報を抽出寸ること在考え ている。白い領域の座標範囲で画像間減算を行い, そり 後、2值化寸゙。さらに、その画像と人力婳像で論理樍

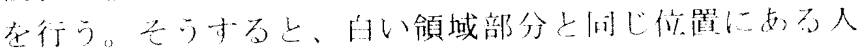
ر曲像の情報が得られる。敦理積在行うのは、曲像間減

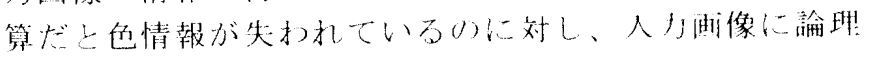

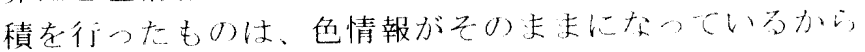
で支る。論理積在行つた後、選手情報の取得在行引。

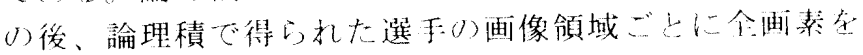

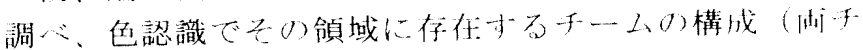

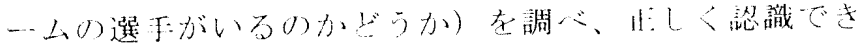

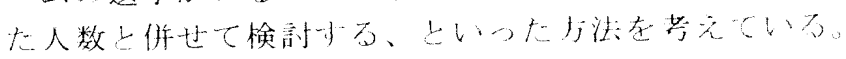




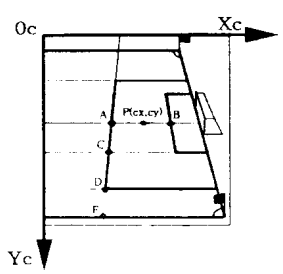

a. Camera coordinates

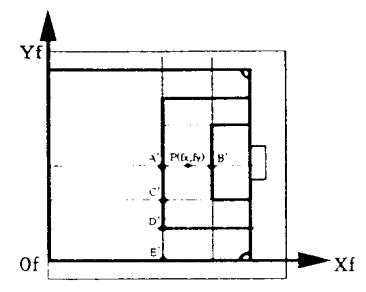

b. Field coordinates
Fig 5 . Coordinates transformation

\section{3 座標変换}

前処理で求好た選手の中心座標は力又亏座標（图５． a) 加で、ーメーション表示古るた如にィールド

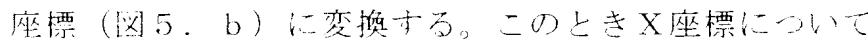

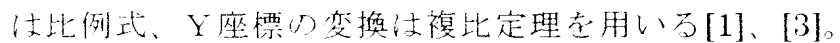

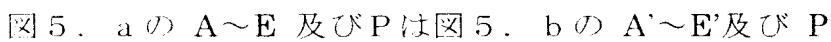

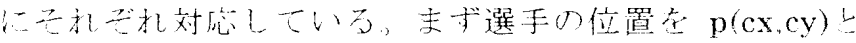

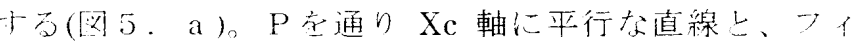
一ルド座標上で Yf 軸に平行である力メラ座標上の) 2 直

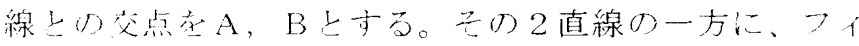
一ルド座標上での值が睡知である3点在選び、それ在C， D， E七寸万。P成座標は、

$$
\mathrm{A} P: \mathrm{AB}=\mathrm{A}^{\prime} \mathrm{P}^{\prime}: \mathrm{A}^{\prime} \mathrm{B}^{\prime}
$$

の比例式で求吉る。また $\mathrm{P}^{\prime}$ ○ 座標 $\mathrm{fy}$ は、

$$
\frac{A D}{C D}: \frac{A E}{C E}=\frac{A^{\prime} D^{\prime}}{C^{\prime} D^{\prime}}: \frac{A^{\prime} E^{\prime}}{C^{\prime} E^{\prime}}
$$

の複比定理で求めることができる。

\section{4 アニメーション表示}

前過程の変換式で求めた座標老元にOpenGL 老使い、 アニメーション表示をする。まず、コートのラインの各 座標は既知なので、それをもとにフィールドのラインを 描く。選手データにはシーン番号も付けているので、同 じシーン番号のデータを描画すればよい。ここで、チー ムごとに選手の描画在変える（色を変える、マークの形 在変える等) 。

アニメーション表示をする際、選手位置をそのまま表 示するモードでは特に問題はないが、優勢領域を加えて 表示寸るモードでは、フィールド在細かく分け、その一 点一点について優勢領域を決めているため、コンピュー 夕についてある程度の演算処理能力がないと快適なアニ メーションとして表示できない。

\section{5 戦術解析}

サッカーの戦術解析は敵選手人のマ一クの解析、パス の精度の測定などいくつかの方法がある。本研究では、 特定のエリアにどちらのチームが早く到達できるかを考 える『優勢領域解析』を行う。攻撃側では、自チームの 領域にパス出すことによりパスの精度が高くなるだけ でなく、領域を広げることによりパスコースが増え、攻 撃にバリエーションが出てくる。また、守備側では他チ 一ムの領域を狭くするこどによりパスの精度を下げる、 またパスコースを読むといった戦術が期待できる。この

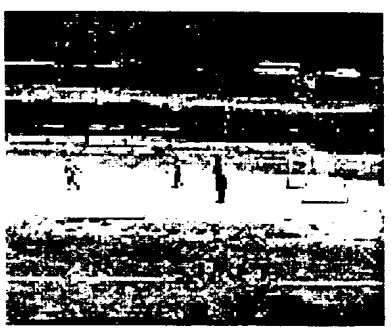

a . Source image 2

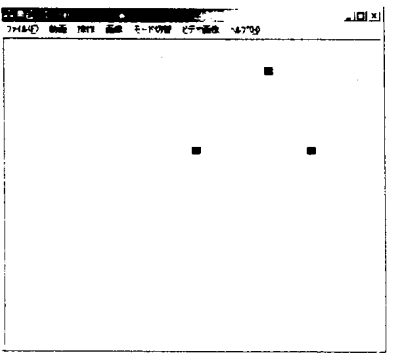

b. Result
Fig 6 . Indicate animation

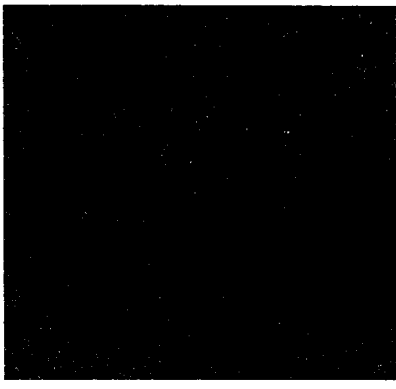

a. Set predominant area

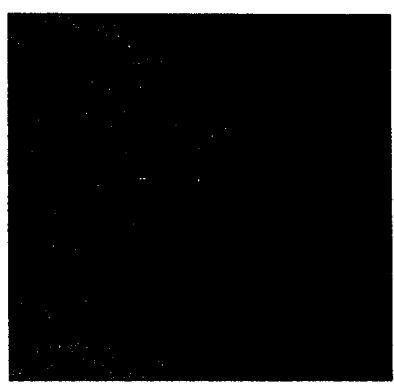

b. Result
Fig 7 . Predominant area

よ5に優勢領域はいくつもの必要性を持っている。今回 は選手個人個人のデー夕は無視するため、選手の足の速 さはわからない。そこで、本研究では暫定的にある地点 に㧍いて各選手上の距離を比心゙、そこを一番近い選手の チームの領域上寸る（図 $7 . \mathrm{a}$ )。また、翼なるチームの 優勢領域が重なった場合は図 7 .b のようになる。この とき、異なるチームの選手で目標との距離が等しい場合、 守備側に優勢領域を与えるものとしている。このように フィールド内のすべての点において優勢領域を決定して いき、す心゙てのシーンに抢いて優勢領域を定めることで 優勢領域を表示するアニメーションが完成する。

優勢領域だけでも十分な戦術解析が行えるが、選手の 見た目や、フィールド内のある地点からの見た目が分か るとよりよい戦術解析ができる。例えば、ある地点にお いて自チームの優勢領域であっても、パスを出して良い かどうかは実際の選手の視点がないと間にいる敵選手と の位置関係は分からない。また、そこが敵チームの優勢 領域であっても、選手視点で見てみるとパスを出せる領 域かもしれない。そこで2 D表示に加えて $3 \mathrm{D}$ を表示寸 る3 D ビューワーを作成する（図 8 ）。3 D ビューワー は2 D表示アプリケーションと同時に起動させておくこ と老想定し、3 D表示も OpenGL 在用いて作成する。 $2 \mathrm{D}$ アニメーション表示中にアニメーションを静止させ、 そのシーンの選手位置データや視点位置データを $3 \mathrm{D}$ ビ ューワーに出力し表示を行う。 $3 \mathrm{D}$ における視点はアニ メーション表示のフィールド内の任意の点を視点として 設定できるようにする。視点決定はマウスでフィールド 内在クリックすれば、その位置にマークがつき同時にそ のシーンの選手データとともに視点データが出力される。 $3 \mathrm{D}$ ビューワーは左右 30 度ずつの回転が可能で、視点 から360度全方向の表示が可能である。また、2 D画 面の選手位置や視点なじの情報が変わると、3 D ビュ一 


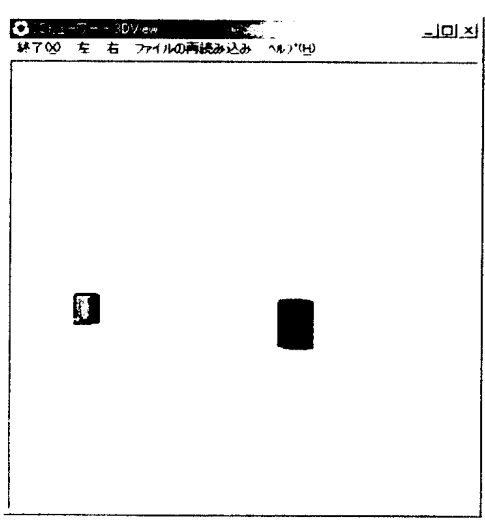

Fig 8 . 3 D view

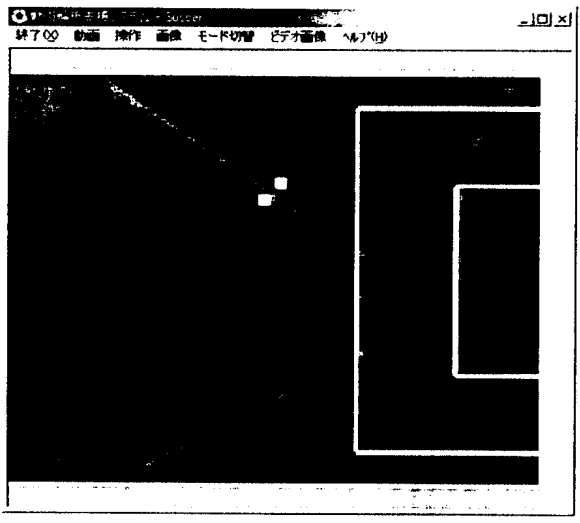

a. Result 1

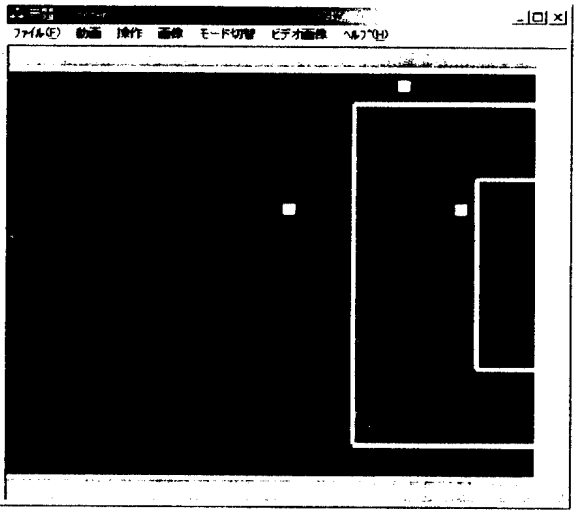

b. Result 2

Fig 9 . Result

ワーでデータの再読み込み䘮行うことで表示の変更がで きる。

\section{3. 実験結果}

本研究では、画像処理に日立 IP_5000 画像処理ボー ドを使用し、ブログラムには Microsoft Visual C++に IP_X 画像処理ボードのライブラリ関数、OpenGL 在用 いて作成した。

今回は 1 チーム選手 2 人の計 4 人で行いユニフォームは 赤と青を用意した。また、試合在想定した動きではなく 故意に離れたり近づいたりしていろいろなシチュエシシ ヨンの画像を撮影し、入力画像しして用いた。図 9 .

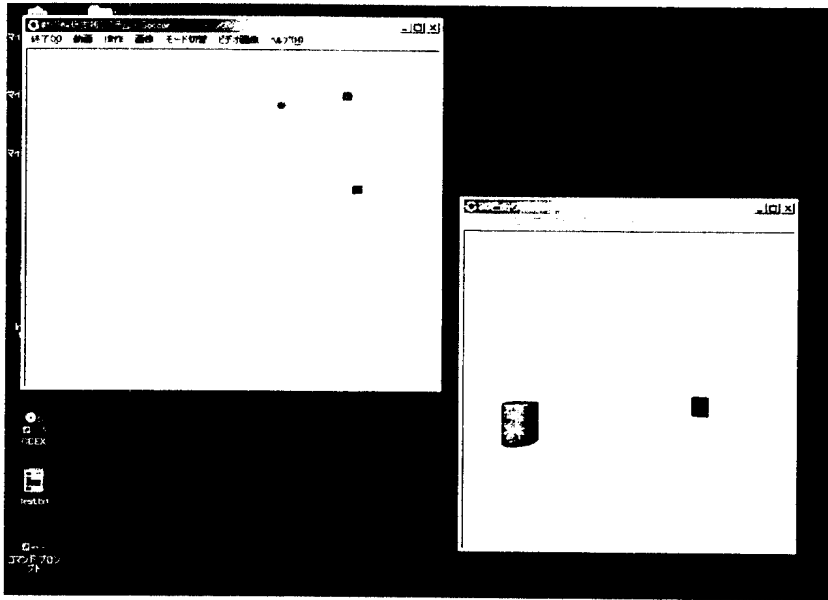

Fig 10 . Scene analyzing
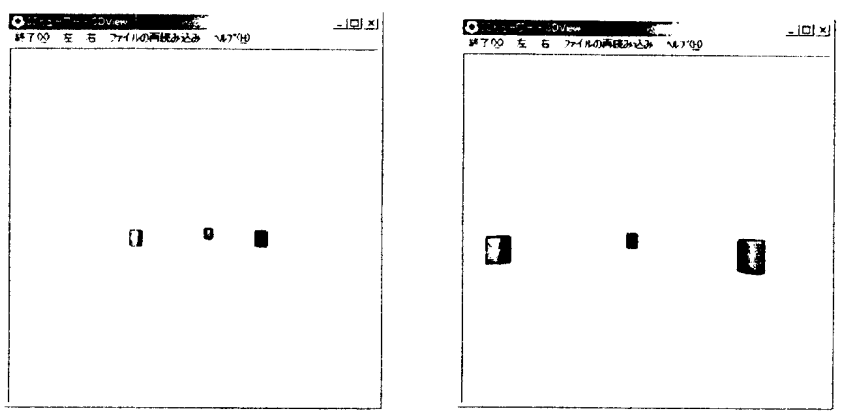

Fig 1 . One scene from different viewpoint

はフィールド内に4人がいるときの優勢領域表表示した ものである。選手の位置の忍じて優勢領域が描かれ、今 後の選手の動きを予測及び指示することが容易になる。

図 9.b汢一見しただけでは赤チームが 2 人に青チーム が 1 人の状態の上うに見えるが、実際の青チ一ムは2人 である。これは、セクション 2.2 で指摘した問題のため に、一人として認識されてしまい正しい表示ができなく なっている。今回は支援システム在想定しているので、 手作業による訂正が可能である。

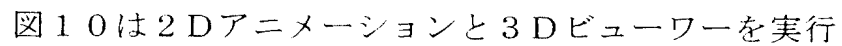

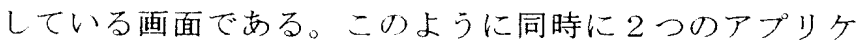
一ション枈実行し、2つの画面在合わせて戦術解析在行 うっこのように2つのアブリケーションを同時に起動し、 同じシーンでもあらゆ西視点からのシーンの再現及び、 解析が可能である。図 11 仕同じシーンを違う視点から 見たものだある。このように視点孝変えるだけでも戦術 解析の幅は広がるものである。

\section{4.まとめ}

本研究では、数ある戦術解析法として、選手を検出し その位置関係を割り出し、チーム別に分けてよ゙ちらのチ 一ムの選手がその領域に早く到達できるかを求める優勢 領域解析を行ってきた。しかし、途中で述べてきたよう に個々の選手のデータについては切り捨てて考えている ので、選三に依存寸る解析（ある選手なら多少相手の優 
勢領域であっても追いつける足の速さを持っている、女 石選手はボーールコントロールがうまい、など）は行えな くなった。しかし、2 ウアニメーションと３１ビューワ 一在併せることで2 Dアニメーションだけ、またカメラ 映像だけの解析だけでは見えない情報も見えてくる。例 えば、2リでは全体が見えるため自チー公の優勢領域は

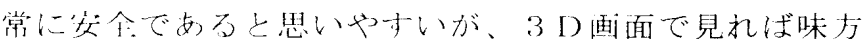

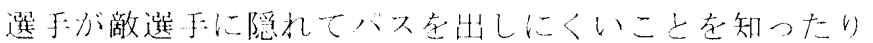
去た、選丁り場になって今後の動きやダームけ進め) 在解析できる

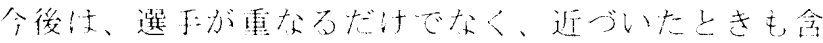

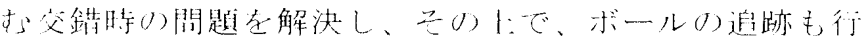

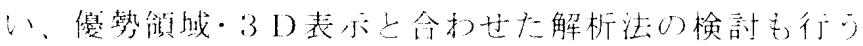

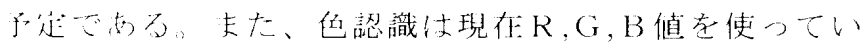

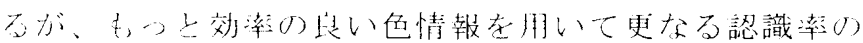
们上在川指寸。乙して最終的には棒際のダームでこのシ 火テム在適用村后こ上在考九ている。

参䓔文献

[1]瀧他，“チームテレー分析老目的としたザカ一

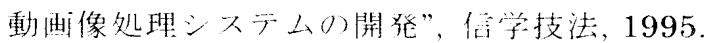

[2] S Sudo and S Ozawa, "Scene analysis of soccer game", QCAV-99, 1999.

[3] 瀧 他, “サッカー映像から○チームワーク評価 今法の検討”，信学技法，1996.

[4]クレイトン・ウォルナム著, 松田兒一訳, Win32 OpenGL プログラミング, 株式会社ブレン ティスホール纯版, 1996. 